\title{
TRAVELLING THE NATIONAL ROUTE: SOUTH AFRICA'S PROTECTION OF INVESTMENT ACT 2015
}

\section{TARCISIO GAZZINI*}

\section{INTRODUCTION}

This note examines the main features of the South African Protection of Investment Act 2015 (hereinafter the 'Act'), ${ }^{1}$ promulgated in January 2016, and provides a preliminary assessment on its adequacy to protect foreign investment, taking into account existing customary international law and investment treaties. It is worth recalling that the adoption of the Act was the culmination of a process aimed at reconsidering the South African approach to the protection of foreign investment. The process started with a three-year review of the bilateral investment treaties (BITs) concluded by South Africa and their impact on both economic growth and regulatory powers. ${ }^{2}$ The results of the review were published in $2009^{3}$ and

* Professor of International Law, University of East Anglia. Contact:

T.Gazzini@uea.ac.uk

1 At https://www.thedti.gov.za/gazzettes/39514.pdf. All websites visited last time on 18 August 2017.

2 As pointed out by the UN Economic Commission for Africa, Committee on Regional Cooperation and Integration, Investment agreements landscape in Africa, 7-9 December 2015, at http://www.uneca.org/sites/default/files/uploadeddocuments/RITD/2015/CRCI-Oct2015/report-on-investment-agreements.pdf, p. 1, ' $[\mathrm{t}]$ he impact of bilateral investment treaties on economic and social development in Africa remains debatable. There is no conclusive evidence regarding the effect of these treaties on foreign investment.' Several authors, including L. Cotula, X. Weng, Q. Ma and P. Ren, China-Africa Investment Treaties: Do they Work? (International Institute for Environment and Development, 2016): 51, at http://pubs.iied.org/pdfs/17588IIED.pdf, have argued that ' $[t]$ here is a strong case for 
revealed that 'the current system [had] open[ed] the door for narrow commercial interests to subject matters of vital national interest to unpredictable international arbitration that may constitute direct challenges to legitimate, constitutional and democratic policy-making. ${ }^{, 4}$ At the international level, the government of South Africa has terminated nine BITs with European countries (Austria, Belgium and Luxembourg Economic Union, Denmark, France, Germany, Italy, the Netherlands, Spain, Switzerland and the United Kingdom), thus reducing the number of BITs in force to 14 , according to the UNCTAD database. ${ }^{5}$ The fact that only BITs with European countries were terminated was described as incidental due to their expiration dates. ${ }^{6}$ More BITs are reportedly in the process of termination. ${ }^{7}$

African governments to conduct rigorous reviews of the performance of their investment treaties, including both costs and benefits.'

3 South Africa Department of Trade and Industry, Bilateral Investment Policy Framework Review, General Notice 961, Government Gazette 32386 (7 July 2009).

4 X. Carim, 'Lessons from South Africa's BITs review', VALE Columbia FDI Perspectives, No. 109, 25 November 2013, at http://ccsi.columbia.edu/files/2013/10/No_109_-_Carim_-_FINAL.pdf. See also R. Davies, Minister of Trade and Industry, 2007 UNCTAD's Investment Policy Framework for Sustainable Development in Geneva, at http://www.dti.gov.za/delegationspeechdetail.jsp?id=2506.

5 Russian Federation, Nigeria, South Korea, Cuba, China, Mauritius, Argentina, Iran, Senegal, Greece, Sweden, Finland, Italy and Zimbabwe. See http://investmentpolicyhub.unctad.org.

6 See Department of Trade and Industry, Responses to Submissions, 16 September 2015, at

http://www.samed.org.za/Filemanager/userfiles/Promotion\%20and\%20Protection\%20of \%20Investment\%20Bill\%20\%20Department\%20response\%20to\%20submissions\%20.p df.

7 According to an unofficial list provided by South Africa's Department of International Relations and Cooperation as per 12 February 2016 (on file with author), notice of termination was given by South Africa with regard to the BITs with Italy, Greece, Cuba 
At the domestic level, a draft of the investment act was published in October 2013 and open to public comment. It ignited a hot debate between the government and the different stakeholders. ${ }^{8}$ The bill was then formally introduced in the National Assembly on 22 July 2015 under the title 'Promotion and Protection of Investment Bill' and eventually promulgated in the final form on 15 December under the final title which dropped the reference to 'promotion'. It consists of 16 articles (including the last three on practical matters and transitional arrangements) and its structure is broadly modelled after traditional BITs, although it presents macroscopic differences compared to them, both substantially and procedurally.

\section{CONTENT OF THE ACT}

\section{A. Definition of Investment}

The Act contains a rather sophisticated definition of investment composed of three categories. Under Section 2.1, an investment is:

(a) any lawful enterprise established, acquired or expanded by an investor in accordance with the laws of the Republic, committing resources of economic value over a reasonable period of time, in anticipation of profit;

and Finland. On South African investment treaty practice and policy, see E. C.

Schlemmer, 'An overview of South Africa's bilateral investment treaties and investment policy', 31 ICSID Review (2016): 167-93.

8 Among the numerous reactions, see European Union Chamber of Commerce and Industry in Southern Africa, 'The promotion and protection of Investment Bill 2013', August 2015, at http://static1.squarespace.com/static/55f93ec2e4b0d99faf1aef57/t/56091fcce4b08574a5 b910be/1443438540876/EU+Chamber+of+Commerce_Parliamentary+Submission_Inv estment+Bill_Shorter_...pdf. 
(b) the holding or acquisition of shares, debentures or other ownership instruments of such an enterprise; or

(c) the holding, acquisition or merger by such an enterprise with another enterprise outside the Republic to the extent that such holding, acquisition or merger with another enterprise outside the Republic, has an effect on an investment contemplated by paragraphs (a) and (b) in the Republic.

Category (a) is reminiscent of the so-called Salini test, based on three elements of the notion of investment, namely 'contributions, certain duration of performance of the contract and a participation in the risks of the transaction'. ${ }^{9}$ Interestingly, no mention is made of the contribution to the development of the host state, which some arbitral tribunals have considered as an additional requirement for the purpose of the definition of investment. ${ }^{10}$

Section 2.2 further provides a comprehensive but non-exhaustive list of assets. The term 'assets', which is presumably used here as synonymous with 'resources' under section 2.1, includes: (a) shares, stocks, debentures, securities or other equity instruments of the enterprise or another enterprise; (b) a debt security of another enterprise; (c) loans to an enterprise; (d) movable or immovable property or other property rights such as mortgages, liens or pledges; (e) claims to money or to any performance under contract having a financial value; (f) copyrights, know how, goodwill or intellectual property rights such as patents, trademarks, industrial designs and trade names; (g) returns such as profits, dividends, royalties or income yielded by an investment; or (h) rights or concessions conferred by law or under contract, including licences to cultivate, extract or exploit natural resources.

9 Salini Costruttori S.p.A. and Italstrade S.p.A. v. Morocco, ICSID ARB/00/4, Jurisdiction, 31 July 2001, para. 52 in fine.

10 See, for instance, Helnan International Hotels A/S v. Egypt, ICSID ARB/05/19, Jurisdiction, 17 October 2006, para. 77. 
The Act does not contain any precise definition of investor. Instead, section 1 laconically defines it in a rather circular manner as an enterprise making an investment. The definition of investor is completed by that of 'enterprise', which clarifies that the Act protects both natural and legal persons, regardless of their incorporation in South Africa. Since nationality is irrelevant for the purpose of the substantive protection granted under the Act, there seems to be no need for a definition of investor similar to those that can be found in investment treaties. However, the nationality of foreign investors is relevant for the purpose of international arbitration between South Africa and the home state, even if such mechanism - whose recourse has been rather exceptional in foreign investment law -is not mandatory under section 13(5) of the Act.

\section{B. General Provisions}

The Act's aims are threefold as enunciated in section 4. First, it purports to protect investment in accordance with and subject to the Constitution, with a view to striking a balance between the rights and interests of the different stakeholders. Second, it affirms and safeguards the sovereign right of South Africa to regulate investments in the public interest. Third, it confirms the application to all investments made in South Africa of the Bill of Rights in the Constitution as well as of all relevant laws.

Section 3 of the Act, which deals with the interpretation of the Act, is an intriguing provision. It provides that the Act must be interpreted and applied in accordance with its purposes, the Constitution - including the interpretation of the Bill of Rights, customary international law and international law, governed respectively in sections 39, 232 and 233 of the Constitution - as well as relevant international treaties to which South Africa is or becomes a party.

Section 39 (Interpretation of Bill of Rights) reads: 
1. When interpreting the Bill of Rights, a court, tribunal or forum (a) must promote the values that underlie an open and democratic society based on human dignity, equality and freedom; (b) must consider international law; and (c) may consider foreign law.

2. When interpreting any legislation, and when developing the common law or customary law, every court, tribunal or forum must promote the spirit, purport and objects of the Bill of Rights. ${ }^{11}$

Section 232 deals with the legal status of customary international law in the South African legal system and establishes that customary international law is law in the Republic unless it is inconsistent with the Constitution or an Act of Parliament.

Interestingly, section 3 of the Act does not contain any reference to section 231.4 of the Constitution, the equivalent for international treaties of section 232. Section 231.4 states that international treaties become law in the Republic when enacted into law by national legislation, whereas self-executing provisions contained in international treaties approved by the Parliament are considered as law of the Republic, provided they are not inconsistent with the Constitution or an Act of the Parliament.

According to section 233, finally, when interpreting any legislation, South African courts must prefer any reasonable interpretation of the legislation that is consistent with international law over any alternative interpretation that is inconsistent with it.

The Act applies to all investments falling within the definition of section 2, or, using the terminology of section 5 of the Act, 'to all investments made in accordance with the requirements set out in Section 2'. It also provides that all investments must be established in accordance with domestic law (section 7.1) and clearly excludes any pre-establishment rights (section 7.2).

11 Emphasis added. 


\section{Substantive Rules}

The catalogue of provisions on investment protection of the Act is limited to five. Under section 6, the government must ensure that 'administrative, legislative and judicial processes do not operate in a manner that is arbitrary or that denies administrative and procedural justice' to investors in accordance with the Constitution and relevant legislation. In spite of the absence of any reference to fairness apart from fair public hearing before a court, the section is titled 'Fair administrative treatment' (without any mention of administrative and judicial treatment).

The standard embodied in section 6, which did not appear in the draft submitted in July, is essentially national and based on the prohibition of arbitrary treatment and on denial of administrative and procedural justice as provided in domestic legislation. It is then further substantiated by three renvois to Articles 32 to 34 of the Constitution, concerning, respectively, the right to be given written reasons and administrative review, the right to access to government-held information and the right to a fair public hearing before a court or another independent and partial tribunal or forum.

Reminiscent of the so-called Calvo doctrine, ${ }^{12}$ section 8.1 (National treatment) provides that foreign investors cannot be treated less favourably than domestic investors in like circumstances. Section 8.2 offers a non-exhaustive list of elements that have to be taken into account in order to establish the existence of 'like circumstances', such as (a) the effect of the foreign investment on the Republic and the cumulative effects of all investments; (b) the sector that the foreign investments are in; (c) the aim of any measure relating to foreign

12 On the clause, see, in particular, C. Schreuer, 'Calvo's grandchildren: the return of local remedies in investment arbitration', 4 Law and Practice of International Courts and Tribunals (2005): 1-17. 
investments; (d) factors relating to the foreign investor or the foreign investment in relation to the measure concerned; (e) the effect on third persons and the local community; (f) the effect on employment; and (g) the direct and indirect effect on the environment.

Yet, the scope of application of the national treatment is significantly reduced by the express exclusion of the extension to foreign investors of preferences or privileges resulting, inter alia, from (a) government procurement processes; (b) public subsidies and grants; (c) the promotion of equality or advancement of historically disadvantaged persons, promotion of cultural heritage, indigenous knowledge and related biological resources, or national heritage; and (d) the assistance for or development of small and medium businesses or new industries (section 8.4).

Under section 9 South Africa must ensure the physical security of foreign investors 'as may be generally provided to domestic investors in accordance with minimum standard of treatment of customary international law (MSCIL) and subject to available resources and capacity'.

The Act contains a section reminiscent of, yet significantly different from the other key provision normally found in investment treaties, namely expropriation. Section 10 of the Act confines itself to extending to foreign investors the right to property protected under section 25 of the Constitution, a rather complex provision of more than 350 words. ${ }^{13}$ Section

\section{Section 25 (Property) reads:}

1. No one may be deprived of property except in terms of law of general application, and no law may permit arbitrary deprivation of property. 2. Property may be expropriated only in terms of law of general application (a) for a public purpose or in the public interest; and (b) subject to compensation, the amount of which and the time and manner of payment of which have either been agreed to by those affected or decided or approved by a court. 3 . The amount of the compensation and the time and manner of payment must be just and equitable, reflecting an equitable balance between the public interest and the interests of those affected, having regard to all relevant circumstances, including (a) the current use of the property; (b) 
25 indicates, inter alia, the requirements that are to be satisfied in the case of expropriation: (a) no one may be deprived of property except in terms of law of general application; (b) no law may permit arbitrary deprivation of property; (c) property may be expropriated only for a public purpose or in the public interest, which includes land reform and equitable access to all South Africa's natural resources; and (d) expropriation entails the obligation to pay just and equitable compensation fixed, in case of disagreement, by a domestic court and reflecting an equitable balance between the public interest and the interests of those affected, having regard to all relevant circumstances.

Section 25 of the Constitution further clarifies, inter alia, that the state must take reasonable legislative and other measures, within its available resources, to foster conditions

the history of the acquisition and use of the property; (c) the market value of the property; (d) the extent of direct state investment and subsidy in the acquisition and beneficial capital improvement of the property; and (e) the purpose of the expropriation. 4. For the purposes of this section (a) the public interest includes the nation's commitment to land reform, and to reforms to bring about equitable access to all South Africa's natural resources; and (b) property is not limited to land. 5. The state must take reasonable legislative and other measures, within its available resources, to foster conditions which enable citizens to gain access to land on an equitable basis. 6. A person or community whose tenure of land is legally insecure as a result of past racially discriminatory laws or practices is entitled, to the extent provided by an Act of Parliament, either to tenure which is legally secure or to comparable redress. 7. A person or community dispossessed of property after 19 June 1913 as a result of past racially discriminatory laws or practices is entitled, to the extent provided by an Act of Parliament, either to restitution of that property or to equitable redress. 8. No provision of this section may impede the state from taking legislative and other measures to achieve land, water and related reform, in order to redress the results of past racial discrimination, provided that any departure from the provisions of this section is in accordance with the provisions of section 36(1). 9. Parliament must enact the legislation referred to in subsection (6). 
which enable citizens to gain access to land on an equitable basis, and that nothing in section 9 prevents the state from taking legislative and other measures to achieve land, water and related reform in order to redress the results of past racial discrimination.

The final substantive provision relates to the right of foreign investors to repatriate funds, subject to taxation and other applicable legislation (section 11).

\section{Right to Regulate}

A key provision of the Act is section 12 (Right to regulate) providing in paragraph 1 that nothing in the Act precludes the adoption by the government, in accordance with the Constitution and applicable legislation, of measures concerning, inter alia: (a) redressing historical, social and economic inequalities and injustices; (b) upholding the basic values and principles governing the public administration; (c) upholding the rights guaranteed in the Constitution; (d) promoting and preserving cultural heritage and practices, indigenous knowledge and biological resources related thereto, or national heritage; (e) fostering economic development, industrialisation and beneficiation; (f) achieving the progressive realisation of socio-economic rights; or $(\mathrm{g})$ protecting the environment and the conservation and sustainable use of natural resources.

Furthermore, under paragraph 2 of section 12, the government or any organ of state may take measures that are necessary to comply with international obligations related to international peace and security, or the protection of security interests, including the financial stability of the Republic. 


\section{E. Procedural Provisions}

With regard to the settlement of disputes between the investor and the government, the Act makes available to the former two types of domestic remedies. Within six months of 'becoming aware of the dispute', the investor may request the Department of Trade and Industry (TDI) 'to facilitate the resolution of such dispute by appointing a mediator' (section 13.1). Under section 13.2, the mediator is appointed by the government and the investor from a list maintained by the DTI, or in the absence of such a list from individuals proposed by either party. If the DTI is party to the dispute, the parties may jointly request the Judge President of one of the divisions of the High Court to appoint a mediator.

Alternatively, under section 13.4 and subject to applicable legislation, an investor, upon becoming aware of a dispute, 'is not precluded from approaching any competent court, independent tribunal or statutory body within the Republic for the resolution of a dispute relating to an investment.'

The Act also foresees the possibility of arbitration between South Africa and the national state of the investor in respect of investments covered by this Act. In this case, the government may consent to international arbitration, subject to the exhaustion of domestic remedies. In considering such a request, the government must respect the administrative processes set out in section 6 of the Act (Fair and administrative treatment). 


\section{PRELIMINARY ASSESSMENT OF THE ACT}

The Act is a strong response to the perceived inadequacy of investment treaties which have attracted growing criticism for three main reasons. ${ }^{14}$ First and in spite of some recent interesting developments and with significant exceptions, ${ }^{15}$ these treaties remain manifestly unbalanced in favour of the investor, to the point that in Spyridon v. Romania, the Tribunal candidly admitted that the BIT between Greece and Romania 'imposes no obligation on investors, only on contracting States'. ${ }^{16}$ Second, investment treaties are often perceived by the host state as unduly restricting its regulatory powers and its capacity to pursue its social and economic policies. Third, investment arbitration is not considered as offering adequate guarantees in terms of legitimacy, transparency and coherence.

The disaffection for investment treaties, combined with the lack of clear evidence that investment treaties increase the flow of foreign investments and stimulate economic growth, ${ }^{17}$ has pushed several states to reconsider their approach to the legal protection of such

14 For a balanced assessment of these treaties, see G. Van Harten, 'Five justifications for investment treaties: a critical discussion', 2 Trade Law and Development (2010): 1-32.

15 See, for example, Supplementary Act Adopting Community Rules on Investment and the Modalities for its Implementation within ECOWAS, 19 December 2008, at http://www.privatesector.ecowas.int/en/III/Supplementary_Act_Investment.pdf; or the BIT concluded between Morocco and Nigeria on 3 December 2016 (not yet in force), see T. Gazzini, "Nigeria and Morocco move towards a "new generation" of bilateral investment treaties', EJIL Talk!, May 2017, http://www.ejiltalk.org.

16 Spyridon v. Romania, ICSID ARB/06/1, Award, 7 December 2011, para. 871.

17 UNCTAD, The Impact of International Investment Agreements on Foreign Direct Investment: An Overview of Empirical Studies 1998-2014, Issues Note, Working Draft, September 2014, available at http://investmentpolicyhub.unctad.org/Upload/Documents/unctad-web-diae-pcb-2014Sep\%2024.pdf. 
investments. States are increasingly reluctant to conclude new BITs. ${ }^{18}$ Some states have opted for a revision of their treaty models with a view to striking a better balance between the rights and obligations of the host state and foreign investors, to properly preserving the policy space of the latter and to revising the remedies available to the investor, with the possible express provision for counter-claims put forward by states. ${ }^{19}$ Other states have preferred to conclude facilitation agreements which radically downgrade the substantive protection of foreign investment and do not provide for judicial or arbitral proceedings against the host state. ${ }^{20}$

The South African government has opted for a different route based on the assumption that domestic legislation is more appropriate than international legal instruments to regulate foreign investment.

The Act is firmly anchored to the Constitution, as is evident first in sections 3 and 4 . The first section indicates that it must be interpreted, inter alia, in accordance with the Constitution. The second enunciates its objectives and subsection (a) eloquently provides that foreign investments are to be protected 'in accordance with and subject to the Constitution'. The Act also contains several references and renvois to the Constitution, most prominently with regard to section 6 (Fair administrative treatment), Section 10 (Right to property) and Section 12 (Right to regulate).

The choice to move away from international treaties in favour to a domestic piece of legislation solidly pegged to the Constitution is an interesting compromise. Domestic

18 Only 25 BITs have entered into force since 1 January 2014.

19 See, most notably, the new Indian BIT model, at http://finmin.nic.in/the_ministry/dept_eco_affairs/investment_division/ModelBIT_Anne x.pdf. See also the 2016 BIT between Morocco and Nigeria, supra, note 15.

20 See, for example, Cooperation and Investment Facilitation Treaties (CFITs) recently concluded by Brazil and Mozambique, at http://www.itamaraty.gov.br/index.\%20php?option=com_content\&view=article\&id=85 $11 \&$ catid $=42 \&$ Itemid $=280 \&$ lang $=$ pt - BR. 
legislation unavoidably exposes foreign investors to greater risks and instability as the legislator may at any time amend the legal rules whereas modifying a treaty requires the agreement of all parties. Pegging the Act to the Constitution, however, significantly mitigates such exposure due to the rigidity of the Constitution, which can be modified only in accordance with a more complex procedure. ${ }^{21}$ Yet the Acts and the Constitution itself make several references to other pieces of domestic legislation, thus paving the way to the 'ordinary' legislative intervention to complete and elaborate on the rules contained in the Act and the Constitution. It is also possible that the consistency of the ordinary legislation with the Constitution is disputed. Here the risks foreign investors are exposed to become more important.

With regard to the substantive provisions, the Act does not impose any new obligations upon the investor. The only obligation expressly mentioned in the Act is the obligation to comply with domestic law, which needless to say exists regardless of any express provision. ${ }^{22}$ From this perspective the legislator has preferred to include in the Act several references to domestic legislation rather than to insert in the Act any obligations for the investors like those that have slowly found their way into investment treaties, such as obligations on transparency, access to documents, consultation, corporate social responsibility, corruption or social and environmental impact assessment. ${ }^{23}$

21 See section 74 (Bills amending the Constitution).

22 In Parkerings-Compagniet AS v. Lithuania, ICSID ARB/05/8, Award, 11 September 2007, para. 332, for instance, the Tribunal pointed out that '[i]t is each State's undeniable right and privilege to exercise its sovereign legislative power. A State has the right to enact, modify or cancel a law at its own discretion.'

23 See, for instance, Chapter III of ECOWAS Supplementary Act on Foreign Investment, or the 2016 BIT between Morocco and Nigeria, supra, note 15. 
Moving to the catalogue of provisions protecting foreign investors contained in the Act, the key provision on fair administrative treatment (section 6) is significantly different from the fair and equitable treatment (FET) normally found in investment treaties. ${ }^{24}$ FET is a rather vague international standard that investment tribunals have progressively shaped through a largely consistent body of decisions. ${ }^{25}$ As pointed out by a tribunal, the standard:

encompasses inter alia the following concrete principles: the State must act in a transparent manner; the State is obliged to act in good faith; the State's conduct cannot be arbitrary, grossly unfair, unjust, idiosyncratic, discriminatory, or lacking in due process; the State must respect procedural propriety and due process. The case law also confirms that to comply with the standard, the State must respect the investor's reasonable and legitimate expectations. ${ }^{26}$

24 See, for instance, Article 3.1 of the BIT between South Africa and China, according to which:

Investments and activities associated with investments of investors of either Contracting Party shall be accorded fair and equitable treatment and shall enjoy protection in the territory of the other Contracting Party. Neither Contracting Party shall in any way impair by unreasonable or discriminatory measures the management, maintenance, use, enjoyment or disposal of investments in its territory of investors of the other Contracting Party.

25 As pointed out in Total S.A. v. Argentina, ICSID ARB/04/01), Liability, 27 December 2010, para. 109: '[T]ribunals have endeavoured to pinpoint some typical obligations that may be included in the standard, as well as types of conduct that would breach the standard, in order to be guided in their analysis of the issue before them.'

26 Rumeli Telekom A.S. and Telsim Mobil TelekomunikasyonHizmetleri A.S. v. Kazakhstan, ICSID ARB/05/16, Award, 29 July 2008, para. 609. 
Such concrete principles are regularly recognised and applied by the generality of states within their respective jurisdictions as well as by international arbitral tribunals.

The standard contained in section 6 of the Act, on the contrary, does not go much further than confirming the protection granted to investment in the Constitution. It does not make any express reference to non-discriminatory measures presumably in order to avoid any risk of restricting the regulatory powers of South Africa, especially with regard to the implementation of policies aimed at correcting past discriminatory measures. ${ }^{27}$

The distinction between arbitrary measures (or 'arbitrary deprivation of property' using the wording of Article 25 of the Constitution) and discriminatory measures has emerged sufficiently clearly in international law and in foreign investment law in particular. ${ }^{28}$ The former category possesses a manifestly negative connotation since arbitrary measures inflict damage on the foreign investor without serving a legitimate purpose ${ }^{29}$ or bear 'no rational relationship [...] between a measure adopted by the government and the alleged purpose or goal of that measure'. ${ }^{30}$ Relying on both ICJ jurisprudence ${ }^{31}$ and dictionaries, several

27 It is worth noting that BITs concluded by South Africa normally prohibit unreasonable or discriminatory measures; see, for instance, Article 41.1 of the BIT with China, Article 4.1 of the BIT with Nigeria and Article 3.1 of the BIT with Argentina.

28 The Expropriation Bill adopted in 2015 aims at ensuring that 'expropriation does not take place arbitrarily and takes place only for a public purpose or in the public interest' (section 2.1), at http://www.gov.za/sites/www.gov.za/files/b4-2015_150213_edited.pdf. In the literature, see C. Schreuer, 'Protection against arbitrary or discriminatory measures', in R. P. Alford and C. A. Rogers (eds), The Future of Investment Arbitration (Oxford University Press, 2009): 183, with reference to some arbitral decisions in footnote 60 .

29 Ibid., especially p. 198.

30 P. Dumberry, 'The prohibition against arbitrary conduct and the fair and equitable treatment standard under NAFTA Article 1105', 15 Journal of World Investment and Trade (2014): 117-51, at 122-3. According to UNCTAD, Fair and Equitable 
investment tribunals have described arbitrary measures or means as 'derived from mere opinion', 'capricious', 'unrestrained', 'despotic', 'fixed or done capriciously or at pleasure', 'without adequate determining principle', 'depending on the will alone', 'without cause based upon the law'. ${ }^{32}$ In a similar vein, the South Africa Constitutional Court has held that a conduct is arbitrary when 'capricious or proceeding merely from the will and not based on reason or principle' ${ }^{33}$

The choice made in section 6 to not expressly refer to discriminatory conduct is of great importance from the standpoint of the exercise of regulatory powers by South Africa. South African authorities may adopt measures having - probably de facto - discriminatory nature, but not amounting to arbitrariness, in pursuing their public policies, including those

Treatment (2012) p. 78, arbitrary measures are 'derived from mere opinion', 'capricious', 'unrestrained', 'despotic' or 'founded on prejudice or preference rather than on reason or fact'.

31 In Elettronica Sicula S.P.A. (ELSI), Judgment, ICJ Reports 1989, p. 15, at p. 76, the Court described an arbitrary conduct as 'wilful disregard of due process of law, an act which shocks, or at least surprises, a sense of juridical propriety'. In the ColombianPeruvian Asylum Case, Judgment, ICJ Reports 1950, p. 266, at p. 284, it was held that '[a]rbitrary action is substituted for the rule of law. Such would be the case if the administration of justice were corrupted by measures clearly prompted by political aims.'

32 See, for instance, Siemens A.G. v. Argentina, ICSID ARB/02/8, Award, 17 January 2007, para. 318. In Methanex v. United States, Award, 3 August 2005, Part IV, Chapter B, para. 1, the Tribunal referred to 'malign intent'. On the application of the notion of arbitrariness, see, in particular, V. Heiskanen, 'Arbitrary and unreasonable measures', in A. Reinisch (ed.), Standards of Investment Protection (Oxford University Press, 2008): 87; J. Stone, 'Arbitrariness, the fair and equitable treatment standard and the international law of investment', 25 Leiden Journal of International Law (2012): 77.

33 Beckingham v. Boksburg Liquor Licencing Board 1931 TPD 280, at 282, and Johannesburg Liquor Licencing Board v. Kuhn 1963 (4) SA 666 (A), at 671C. 
intended to redress the consequences of past discriminatory measures, to promote the wellbeing of historically disadvantaged categories or to implement land reform. From this perspective, section 6 must be read together not only with the relevant parts of the Constitution and the 2015 Expropriation Bill, but also with section 9 of the Constitution and section 12 of the Act on the power to regulate.

It is true that section 6 requires South Africa to ensure administrative and procedural justice. Such a requirement, however, relates to access to the competent tribunals or other bodies as well as the proper administration of justice. Yet, it may be argued that such a requirement does not undermine measures adopted by public authorities to pursue public policies, even if they may be discriminatory against foreign investors, provided that the later have access to justice and justice is properly administered.

The national treatment standard contained in section 8 is in principle comparable with that guaranteed by investment treaties, if not for its source. ${ }^{34}$ The innovative element is the detailed yet non-exhaustive list of elements to be taken into account to determine the existence of 'like circumstances', which appears to be well articulated and may be expected not only to facilitate the application of the Act, but also to enhance the predictability and consistency of the related judicial and arbitral decisions.

The specifications in section 8.4 , however, water the standard down by carving out broadly worded exceptions to the extension to foreign investors of the treatment reserved to

34 Article 10(1) of the BIT with China, for instance, provides that:

If the treatment to be accorded by one Contracting Party in accordance with its laws and regulations to investments or activities associated with such investments of investors of the other Contracting Party is more favourable than the treatment provided for in this Agreement, the more favourable treatment shall be applicable. 
domestic investors. In spite of the apparent close character of the list of exceptions, section 8.4 leaves the government great room for manoeuvre, especially when it comes to promoting the achievement of equality, cultural heritage and practices or developing small, medium or new industries.

The policy space of the government is further safeguarded by section 12 on the right to regulate, this time with a non-comprehensive list of categories of measures. It must be noted that these measures do not need to be necessary to protect certain social interests - such as the environment or public health. They allow a proactive role for South Africa and their general nature makes it difficult for investors to obtain any administrative or judicial control beyond compliance with the procedural guarantees contained in section 6 of the Act as well as the principles of good faith, proportionality and reasonableness.

While it is certainly legitimate to ensure that the host state is able to exercise its rights and fulfil its duties, ${ }^{35}$ the combination of sections 8.4 and 12 substantially weakens the protection of foreign investments. One may wonder whether a more balanced approach could be inspired by provisions contained in existing BITs, such as the Article 3(3)(c) BIT between South Africa and the Czech Republic (not in force yet), which excludes foreign investors

35 As pointed out with regard to investment treaties by the Commonwealth Investment Experts Group Meeting for the African Region, 'Summary Record', Kampala, 20-21 October 2011:

One common issue is the need to clarify the interaction between international investment instruments and domestic investment policy as well as policy in other areas - for e.g., sustainable development and environmental regulation. Governments must always be concerned about ensuring that there is sufficient policy space for them to engage in reconciling competing interests. (http://secretariat.thecommonwealth.org/files/243514/FileName/FINALIEGOutcomesS ummary\%282\%29.pdf) 
from the enjoyment of any treatment preference or privilege which may be granted by the host state in relation to 'any law or other measure the purpose of which is to promote the achievement of equality in its territory, or designed to protect or advance persons, or categories of persons, previously disadvantaged by unfair discrimination'. ${ }^{36}$

Section 9 on the legal protection of property is not particularly well drafted as MSCIL by definition applies only to foreign investors while the use of the modal 'may' with reference to the protection accorded to domestic investors seems rather ambiguous. More importantly, it limits the protection to physical security and introduces a limitation to the related obligation to the available resources. Both treaty practice and arbitral awards vary significantly with regard to whether the obligation to ensure full protection goes beyond physical security. ${ }^{37}$ The standard protected under section 9 therefore cannot be considered as a departure from current practice, but rather a confirmation of a tendency to reduce it to physical security. ${ }^{38}$

36 Article 4 bis of the Protocol to the BIT with Iran, likewise, excludes the extension to investors of the benefit of any treatment, preference or privilege resulting, inter alia, from:

any law or other measure taken, pursuant to Article (9) of the Constitution of the Republic of South Africa, 1996 (Act 108, 1996) the purpose of which is to promote the achievement of equality in its territory, or designed to protect or advance persons, or categories of persons, disadvantaged by unfair discrimination.

37 See, in particular, J. K. Foster, 'Recovering "protection and security": the treaty standard's obscure origins, forgotten meaning, and key current significance', 45 Vanderbilt Journal of Transnational Law (2012): 1095-156.

38 See, for instance, Article 3.2 Indian model BIT, according to which 'full protection and security only refers to a party's obligations relating to the physical security of investors and to investments made by the investors of the other Party and not to any other obligation whatsoever.' 
Section 10 of the Act (Protection of property) - which is essentially a renvoi to section 25 of the Constitution - does not reassure foreign investors. First of all, it deals only with direct expropriation, i.e. transfer of the title to property, and not also to indirect expropriation, which today is by far the most frequent form of deprivation of property. ${ }^{39}$ Second, it expressly imposes only three of the four requirements imposed by international law to lawfully expropriate foreign investment, namely public interest, respect of procedural rules and compensation. In line with the approach taken with regard to national treatment standards and right to regulate, mention is made to arbitrary measures but not to discriminatory measures.

Furthermore, foreign investors may suffer the consequence of measures aimed at redressing past racial discrimination, realising land reform and promoting equitable access to all South Africa's natural resources. These measures can be described as 'positive discrimination' and are certainly legitimate from a social and political standpoint. From a strictly legal perspective, however, section 10 calls for caution due to the vagueness and subjectivity of the just and equitable level of compensation, which reflects an equitable balance between the public interest and the interests of those affected. This is definitely much less satisfactory, from the foreign investor's standpoint, than the 'prompt, full and adequate' formula that can be found, in different variants, in the overwhelming majority of investment treaties. $^{40}$

If the substantive provisions of the Act can scarcely meet the level of protection normally offered by investment treaties, settlement via the dispute mechanism appears to be hardly satisfactory. Mediation is certainly to be encouraged for several reasons, including the higher probability to continue - if not to strengthen - the underlying business partnership as well as the flexibility it offers, especially with regard to expropriation, by allowing the parties

39 See, for instance, Article 4.1 of the BIT between South Africa and China.

40 See, for example, Article 6.1 of the BIT between South Africa and Argentina. 
to avoid the gamble of either getting full compensation or no compensation at all. ${ }^{41} \mathrm{By}$ definition, however, its effectiveness depends on the concerned parties' commitment and willingness to settle the dispute in a friendly manner. The exercise may be frustrated by the financial implications of the dispute or by political considerations and public pressure, especially when the dispute relates to investments in sensitive sectors.

Leaving aside diplomatic protection, in the absence of an applicable treaty providing for international arbitration, foreign investors in South Africa may only have recourse domestic adjudicatory bodies which are not necessarily courts. The settlement of the dispute before domestic courts, tribunals or statutory bodies provided for in section 13.4 calls for several comments. To start with, the remedy in section 13.4 is independent from any attempt to settle the dispute through mediation. Besides, the verb 'to approach' used to describe the initiation of the proceeding under section 13.4 is not particularly felicitous. Perhaps more importantly, section 13.4 must be read in conjunction with section 6.4 (a fortiori considering that under section 6.4 the latter is subject to the former). However, it remains unclear what are the effects of the renvoi operated by section 6.4 to Article 34 of the Constitution, according to which the dispute could be settled by a court or, where appropriate, another independent and impartial tribunal or forum.

The reference in section 6.4 to disputes 'that can be resolved by the application of law', moreover, remains rather cryptic and apparently assumes the existence of disputes that cannot be resolved by the application of law. This begs the question of what are the criteria to establish whether a dispute is susceptible to be settled by the application of law, who will make the related determination and what happens to disputes that cannot be settled by the application of the law.

41 See the symposium on 'Alternative Dispute Resolution in Investment Disputes', 29 ICSID Review (2014): 1. 
Furthermore, the abandonment of investment-state arbitration is a rather drastic measure. Investment arbitration has been celebrated by numerous tribunals and in the literature as a remarkable development bringing the dispute outside the reach of politics with a view to ensuring the equalities of the parties in efficient proceedings conducted by independent tribunals. ${ }^{42}$ While there is no doubt that investment arbitration presents several problems, ${ }^{43}$ it remains to be seen whether the bald move backward made by the Act was indispensable or whether South Africa could have better calibrated the exposure of the host state (for instance, by restricting or conditioning access to arbitration, or by expressly introducing counter-claims) and enhance transparency, participation and public scrutiny.

The settlement of disputes through state-state arbitration, which completes section 13, is hardly satisfactory, not only because it is entirely voluntary, but also because states are traditionally rather reluctant to resort to this kind of arbitration. ${ }^{44}$ Equally important, even assuming arbitration under section 13 is possible, the entire proceedings and all decisions related to the dispute (including a possibly friendly settlement or an agreement on compensation) will be firmly in the hand of the home state with all the associated shortcomings and implications. With regard to the proceedings, furthermore, the silence of the Act on the determination of the nationality of foreign investors unavoidably adds further uncertainty on the entire procedure.

42 See, for example, Gas Natural SDG v. Argentina, ICSID ARB/03/10, Jurisdiction, 17 June 2005, paras $29 \mathrm{ff}$.

43 See, in particular, M. Waibel, A. Kaushal, K.-H. L. Chung and C. Balchin (eds), The Backlash against Investment Arbitration (Kluwer, 2010); and J. Kalicki and A. JoubinBret (eds), Reshaping the Investor-State Dispute Settlement System (Brill-Nijhoff, 2015).

44 See M. Potestà, 'State-to-state dispute settlement pursuant to bilateral investment treaties: is there potential?', in N. Boschiero et al. (eds), International Courts and the Development of International Law. Essays in Honour of T. Treves (Springer, 2013): 753. 


\section{THE ACT AND CUSTOMARY INTERNATIONAL LAW}

The drastic move realised by the Act toward the protection of foreign investment through national legislation rather than international treaties requires a careful examination of the protection foreign investors may still expect under customary international law, keeping in mind, in addition to the Act itself, both Articles 232 and 233 of the Constitution. ${ }^{45}$

Customary international law is relevant from four different, but intimately related, perspectives. In the first place, being law in South Africa in accordance with Article 232 of the Constitution, customary international law may become part of the applicable law, a fortiori when the Act refers to the relevant laws of the Republic, provided it is not inconsistent with the Constitution or an Act of the Parliament. Within these limits, for example, international customary rules may contribute alongside the Constitution and other relevant laws to the definition of the standard of treatment of foreign investors.

Secondly, customary international law must be taken into account when interpreting both the Act and the Bill of Rights the Act relies upon under sections 3 and 4. On the one hand, the Act must be interpreted and applied in a manner that is consistent, inter alia, with customary international law (section 3(b)(ii)). On the other hand, under section 39 of the Constitution, in interpreting the Bill of Rights contained in the Constitution the interpreter must consider international law.

Thirdly, as provided in section 233 of the Constitution, domestic tribunals must prefer any reasonable interpretation of any legislation which is consistent with international law, which includes customary international law. This section mitigates the priority given to the

45 On the relationship between international customary law and the domestic legal system in South Africa, see J. Dugard, 'International law and the South African Constitution', 1 European Journal of International Law (1997): 77-92. 
Constitution or an Act of the Parliament over customary international law and ultimately aims at enhancing compliance by South Africa with its international legal commitments.

Finally, section 9 of the Act directly refers to the minimum standard of customary international law as the benchmark of the level of physical security South Africa has to ensure for the investor, subject to available resources.

All these provisions make customary international law almost ubiquitous in the interpretation and application of the Act. It may be expected that tension will arise when customary international law, on the one side, and the Act or other domestic legislation, on the other, cannot be accommodated through the interpretative process.

It must be emphasised from the outset that the adoption of the Act does not affect in any way the international obligations of South Africa under customary international law. Few principles of international law are as well-established as the one precluding states from relying on domestic legislation to eschew their international obligations. ${ }^{46}$ It follows that, regardless of the adoption of the Act, South Africa is and remains bound to comply fully with customary international law.

The two provisions most likely to pose problems are section 6 (Fair administrative treatment) and section 10 (Legal protection of investment). As noted above, section 6 departs from the international standards applied in investment law, namely the conventional fair and equitable treatment and the customary international minimum standard, in favour of an essentially domestic standard. Under section 6, South Africa is expressly required to refrain from operating arbitrarily in 'administrative, legislative and judicial processes' and not to deny administrative and procedural justice. The text lacks precision. The use of undefined

46 Among many examples, see Free Zones of Upper Savoy and the District of Gex, PCIJ Series A, No. 24, p. 12 (1930). 
expressions such as 'administrative, legislative and judicial processes' and reference to such a broad notion as 'justice' may prove difficult to interpret and apply.

From the standpoint of the foreign investor, the omission of any reference to nondiscrimination may be rather disappointing. It remains to be seen whether and to what extent South African competent authorities and tribunals charged with implementing the Act and settling the related disputes will consider non-discrimination as part of the fair administrative treatment, possibly finding guidance from investment awards and the practice of human rights treaties ratified by South Africa and most importantly the UN Covenant on Civil and Political Rights and the African Charter of Human and Peoples' Rights. The challenge - as is often the case in foreign investment law - is to weigh the legal protection of foreign investors against the rights and duties of the host states to pursue their public policies as well as the interests of other stakeholders.

With regard to section 10, two challenging questions may be expected to arise and generate tension between the international obligations incumbent upon South Africa on the one hand and both the Act and the relevant domestic legislation on the other. The first relates to claims of discriminatory expropriation as section 25 of the Constitution - to which section 10 of the Act refers - expressly proscribes only arbitrary expropriation. Similarly to section 6, the omission of any express reference to the non-discrimination requirement unavoidably creates uncertainty.

The second question concerns indirect expropriation. It is now well established, as pointed out by several tribunals, that:

[e]xpropriation [...] includes not only open deliberate and acknowledged taking of property, such as outright seizure or formal or obligatory transfer of title in favour of the host State, but also covert or incidental interference with the use of property which 
has the effect of depriving the owner, in whole or in significant part, of the use or reasonably-to-be-expected economic benefit of property even if not necessarily to the obvious benefit of the host State. ${ }^{47}$

It appears that section 25 of the Constitution, to which section 10 of the Act refers, is not sufficiently clear with regard to what amounts to indirect expropriation and what the consequences of indirect expropriation are. It introduces a distinction between 'deprivation' and 'expropriation'. The former corresponds in good substance to or at least includes indirect expropriation. According to the South Africa Constitutional Court:

the taking away of property is not required for a deprivation of property to occur. Whether there has been a deprivation depends on the extent of the interference with or limitation of use, enjoyment or exploitation. It is not necessary in this case to determine precisely what constitutes deprivation. No more need be said than that at the very least, substantial interference or limitation that goes beyond the normal restrictions on property use or enjoyment found in an open and democratic society would amount to deprivation. ${ }^{48}$

47 Metalclad v. Mexico, ICSID ARB(AF)/97/1, Award, 30 August 2000, para. 103.

48 Mkontwana v. Nelson Mandela Metropolitan Municipality and Another, Case CCT 57/03, 6 October 2004, at http://www.saflii.org/za/cases/ZACC/2004/9.pdf, para. 32 (footnote omitted), the South Africa Constitutional Court, relying on First National Bank of SA Ltd t/a Wesbank v. Commissioner, South African Revenue Service and Another, Case CCT 19/01, 16 May 2002, at http://www.saflii.org/za/cases/ZACC/2002/5.pdf, para. 57. 
Importantly, deprivation does not trigger any obligation to compensate. In Agri South Africa v. Minister for Minerals and Energy, the South Africa Constitutional Court held that:

[d]eprivation within the context of section 25 includes extinguishing a right previously enjoyed, and expropriation is a subset thereof. Whereas deprivation always takes place when property or rights therein are either taken away or significantly interfered with, the same is not necessarily true of expropriation. Deprivation relates to sacrifices that holders of private property rights may have to make without compensation, whereas expropriation entails state acquisition of that property in the public interest and must always be accompanied by compensation. ${ }^{49}$

Conversely, compensation is due only in case of expropriation, which apparently presupposes a transfer of the title to property. As pointed out by the Constitutional Court, '[t]here can be no expropriation in circumstances where deprivation does not result in property being acquired by the state. ${ }^{50}$

It may be provisionally concluded that, whatever the righteousness of the measures depriving foreign investors of the enjoyment of their investments, the Act does not provide adequate protection against expropriation. ${ }^{51}$ Given the text of section 25 of the Constitution,

49 Agri South Africa v. Minister for Minerals and Energy, Case CCT 51/12[2013] ZACC 9, 18 April 2013, at http://www.saflii.org/za/cases/ZACC/2013/9.html, para. 48 (footnotes omitted, emphasis added).

50 Ibid., para. 59, relying on Reflect-All 1025 CC and Others v. MEC for Public Transport, Roads and Works, Gauteng Provincial Government and Another, Case CCT 110/08, [2009] ZACC 24, http://www.saflii.org/za/cases/ZACC/2009/24.pdf, para. 64.

51 In the same sense, see S. Woolfrey, 'The emergence of a new approach to investment protection in South Africa', in S. Hindelang and M. Krajewski (eds), Shifting Paradigm 
the status of customary international law in the domestic legal system and the jurisprudence of the Constitutional Court, it may be expected that customary international law will have little impact on domestic proceedings. This unavoidably affects the protection foreign investors are entitled to under customary international law and exposes South Africa to the risk of not complying with the related obligations.

\section{THE ACT AND INTERNATIONAL TREATIES}

The Act has to be considered also with regard to the impact or potential impact on BITs currently applicable to South Africa. Keeping in mind the significant lower level of legal protection granted to foreign investors under the Act compared to that normally provided in these treaties, the question is worth exploring from three different perspectives.

In the first place, several of the BITs binding South Africa contain preservation of rights clauses ensuring, inter alia, that legislation - existing at the time of the conclusion of the treaty or adopted subsequently - that is more favourable to the foreign investor would prevail over an inconsistent treaty provisions. The ratio of these clauses is quite straightforward: to ensure that the treaty does not deprive foreign investors of the better protection they may be entitled to under domestic legislation.

It remains to be seen whether these clauses could be interpreted as providing foreign investors with a shield against legislation that could unfavourably affect the treatment they are entitled to under the relevant BIT. It can be argued that a contrario and teleological arguments pave the way to a plausible interpretation of these clauses in the sense of neutralising legislation existing at the time of the conclusion of the treaty or adopted subsequently that would detract from the rights protected under the treaty. From this

in International Investment Law. More Balanced, Less Isolated, Increasingly

Diversified (Oxford University Press, 2016): Chapter XI. 
perspective, the fact that these clauses expressly provide for the application of more favourable provisions of domestic legislation may be read as implying than provisions having the opposite effect do not apply. ${ }^{52}$ This interpretation may be even more convincing when the relevant clause refers to the application to foreign investors of domestic legislation 'to the extent' it is more favourable to them, as in the case of the BITs with Nigeria or Finland ${ }^{53}$ It remains to be seen whether domestic courts or arbitral tribunals will share this interpretation. The major obstacle for such an interpretation lies in the fact that while the priority given to legislation more favourable to investors over the relevant treaty provisions is perfectly respectful of the sovereignty of the host state, neutralising legislation less favourable to investors affects the regulatory powers of that state and amounts to a form of 'immunity' from subsequent legislation reminiscent of that offered by stabilisation clauses.

The second perspective relates to litigation before domestic tribunals, which is expressly provided for in most - but not all ${ }^{54}$ - BITs currently applicable to South Africa, sometimes within fork-in-the-road provisions ${ }^{55}$ Considering the distinct advantages normally offered by international arbitration, ${ }^{56}$ it may be expected that foreign investors in South Africa

52 According to A. Newcombe and L. Paradell, Law and Practice of Investment Treaties. Standards of Treatment (Kluwer, 2009): 478, a preservation of rights clause 'simply says that in applying and enforcing the existing protection offered by the [treaty], attention should be paid to any favourable, but not unfavourable, provision contained in domestic law.'

53 In both cases Article 11(1).

54 Article 8(2) of the BIT with Nigeria is silent on domestic remedies.

55 See Article 8(2) of the BIT with the Czech Republic (not in force yet). Article 12(3) of the BIT with Iran reads: 'National courts shall not have jurisdiction over any dispute referred to Arbitration.'

56 See supra, note 42. 
may be less than enthusiastic about having recourse to domestic tribunals, especially with the presence of fork-in-the-road clauses.

Should disputes concerning alleged violations of BITs reach domestic courts, several questions may arise with regard to both the status of the treaty and its coordination with the Act. ${ }^{57}$ Under the Constitution, a treaty is binding for South Africa only after being approved by the Parliament, with the exception of technical, administrative and executive agreements (section 231(2) and (3) of the Constitution). ${ }^{58}$ It becomes law in South Africa through incorporation and possesses the same status as the act incorporating it. ${ }^{59}$

The status of international treaties in the domestic legal system of South Africa under the 1996 Constitution, however, is still not entirely clear. One author has even argued that '[t]he South African court decisions over the years have [...] fuelled debate rather than

57 On the relationship between international law and domestic law in South Africa, see, in particular, E. de Wet, 'South Africa', in D. Sloss (ed.), The Role of Domestic Courts in Treaty Enforcement. A Comparative Study (Cambridge University Press, 2009): 567-93; J. Dugard, 'South Africa', in D. Shelton (ed.), International Law and Domestic Legal Systems (Oxford University Press, 2011): 448-75; C. Gowar, 'The status of international treaties in the South African domestic legal system: small steps towards harmony in light of Glenister?', 36 South African Yearbook of International Law (2011): 307-25.

58 An agreement can be considered as technical, administrative and executive if it cumulatively satisfies the following criteria: (a) is departmentally specific; (b) does not have major political or other significance; (c) has no financial consequences; and (d) does not affect domestic law. See the opinion on the Economic Assistance Agreement between South Africa and Cuba rendered by the Office of the Chief State Law Adviser on 11 November 2011, at http://pmg-assets.s3-website-eu-west1.amazonaws.com/docs/120808dojcd.pdf, relying on section 5(5) of the Manual on Executive Acts of the President of the Republic of South Africa (2006).

59 See Dugard, supra, note 57, p. 463. 
provided clarity as to the status of international treaties should it conflict with domestic law.' 60

With regard to BITs, furthermore, it is doubtful that these treaties can be considered as technical, administrative and executive agreements, for which no ratification or incorporation is necessary. Such a qualification may be precluded by the political and economic significance of these treaties as well as their financial consequences. Treaty practice of South Africa in this regard seems inconclusive. ${ }^{61}$

It is therefore necessary to double check (a) whether the relevant BIT has been enacted into law by national legislation, thus becoming law in South Africa applicable by domestic judges in accordance with section 231(4) of the Constitution; and (b) the status of the act incorporating the treaty. It is, however, possible that certain provisions contained in BITs are self-executing and as such become law in South Africa, provided that the BIT has been approved by the Parliament and the provisions are not inconsistent with the Constitution or an Act of Parliament (section 233 of the Constitution).

Depending on the outcome of these preliminary questions, domestic tribunals may be able to settle disputes concerning allegations of violations of the relevant BIT. Should this be the case, they will presumably apply the relevant BIT as well as the Protection of Investment Act and other relevant legislation. South African tribunals are directed under section 233 of the Constitution to search for any reasonable interpretation of the Act which is consistent with international law, which includes the BITs and customary international law.

It cannot be excluded that an insurmountable conflict may arise between provisions of the Act and a treaty, most prominently in relation to fair administrative treatment and

60 E. Lai King, 'The Impact of International Developments', February 2015, at http://www.hoganlovells.com/en/publications/the-impact-of-international-developments.

61 On this point, see Schlemmer, supra, note 7, at p. 170. 
expropriation (including compensation). If the treaty has been enacted by subordinate legislation or the treaty provision is applicable due to its self-executing nature, the Act will prevail. But if the treaty has been enacted by act of Parliament, it enjoys the same legal status of the Act and it is difficult to predict how a domestic tribunal would decide. Yet, they must keep in mind that solving the conflict in favour of the Act may amount to non-compliance with the international obligations of South Africa and engage its international responsibility.

The third perspective concerns the possible impact of the Act on international arbitration related to alleged violations of BITs. Several existing BITs expressly include domestic law in the law applicable to the arbitral proceedings, ${ }^{62}$ whereas the BIT with Iran rather unusually directs the arbitral tribunal to have 'due regard' to the host state laws and regulations. ${ }^{63}$

It is now generally accepted, especially when the treaty indicates domestic law as part of the applicable law, that both international law and domestic law have a role to play in investment arbitration. As forcefully pointed out by a tribunal with regard to Article 42 of the ICSID Convention, '[t]he law of the host State can indeed be applied in conjunction with international law if this is justified. So too international law can be applied by itself if the appropriate rule is found in this other ambit. ${ }^{64}$

While several tribunals have emphasised the 'complementary relationship' ('rapport de complémentarité') ${ }^{65}$ or 'close interaction' ${ }^{66}$ between international and domestic rules, in

62 See, for instance, Article 8(4) of the BIT with Nigeria, Article 9(6) of the BIT with China and Article 9(4) of the BIT with Argentina. Article 9(4) of the BIT with Greece, on the contrary, does not include domestic law within the applicable law.

63 Article 12(2).

64 Wena Hotels Ltd. v. Egypt, ICSID ARB/98/4, Annulment, 5 February 2002, para. 40.

65 Antoine Goetz et consorts v. Burundi, ICSID ARB/95/3, Award, 10 February 1999, para. 98. 
the case of unsurmountable conflict between the two in the context of proceedings related to treaty claims international rules are expected to prevail, either by virtue of the international nature of the claim or the professed superiority of international rules. ${ }^{67}$

Yet, foreign investors must be aware that investment tribunals might consider and, if appropriate, apply the Act, especially when domestic law is expressly indicated in the relevant treaty as applicable law. From this perspective, the Act will be 'not an incidental part of the factual background, but an integrated part of the applicable law' ${ }^{68}$

66 CMS Gas Transmission Company v. Argentina, ICSID ARB/01/8, 12 May 2005, para. 117.

67 In $L G \& E$ Energy Corp., LG\&E Capital Corp., and LG\&E International, Inc. v. Argentina, ICSID ARB/02/1, Liability, 3 October 2006, para. 94, for instance, the Tribunal held that 'international law overrides domestic law when there is a contradiction since a State cannot justify non-compliance of its international obligations by asserting the provisions of its domestic law.' In a more nuanced fashion, in Duke Energy Electroquil Partners \& Electroquil S.A. v. Ecuador, ICSID ARB/04/19, Award, 18 August 2008, para. 441, the Tribunal found that ' $[\mathrm{t}]$ he question is not about the preeminence of one rule over the other but about applying the relevant rule depending on the type of norm that has been breached. It is the Tribunal's task to identify the specific rules that dictate the consequences for each of these breaches.' For a full account of the relevant decisions, see H. E. Kjos, Applicable Law in Investor-State Arbitration: The Interplay Between National and International Law (Oxford University Press, 2013), especially Chapter 6. See also C. Schreuer, 'Jurisdiction and applicable law in investment treaty arbitration, 1 McGill Journal of Dispute Resolution (2014): 1-25.

68 I. Alvik, 'The hybrid nature of investment treaty arbitration - straddling the national/international divide', in C. C. Eriksen and M. Emberland (eds), The New International Law: An Anthology (Nijhoff, 2010): 89, at 95. 


\section{CONCLUSIONS}

With the 2015 Protection Investment Act, the pendulum of the rights and obligations in the field of foreign investment has swung decisively in favour of the state. Balancing private and public rights and obligations is more than legitimate, as is switching from international treaties to domestic legislation. What is not convincing is the necessity of the drastic reduction of foreign investors' substantive and procedural rights realised by the Act. It is argued that a better equilibrium could have been achieved by adjusting the existing level of legal protection for foreign investors, either by amending or even renegotiating existing treaties, or by the adoption of domestic legislation properly protecting the interest of foreign investors while preserving the capacity of South Africa to fully exercise its sovereign prerogatives.

South Africa could have reconsidered and possibly limited the rights of foreign investors as well as introduced obligations upon them, including social and environmental impact assessment, corporate social responsibility, consultation, transparency, prohibition of corruption, access to information and documents, and so on. The SADC model BIT and the recent Indian model BIT as well as some modern investment treaties ${ }^{69}$ could have been useful sources of inspiration.

The right to regulate certainly deserves to be adequately safeguarded, with carefully drafted specific or general exceptions, possibly modelled after Article XX GATT, rather than vague and politically charged provisions such as those appearing in the Act. Besides, existing provisions especially designed to allow the adoption by South Africa of the measures necessary to redress past discrimination and injustices ${ }^{70}$ could have been further developed.

69 See supra, note 15.

70 See supra, note 36. 
Moreover, wiping out investor-state arbitration may prove unnecessary if not counterproductive. A variety of options are available between keeping the existing regime and its flat rejection. The current concerns over the legal protection of foreign investment could indeed be addressed by introducing appropriate provisions on the exhaustion of domestic remedies, fork-in-the-road clauses, transparency, access to documents, counterclaims - if not even claims put forward by states against investors - and so on.

It remains now to be seen what impact the Act will have upon the flow of foreign investment to South Africa. Such assessment is particularly arduous for several reasons, including the difficulties in establishing a link between the Act and the evolution of the flow of foreign investment and discharging changes in such flow due to other endogenous and exogenous causes. ${ }^{71}$ Meanwhile, foreign investors might be advised on the complex issued raised by the adoption of the Act with regard to the protection they are entitled to under domestic law as well as under customary international law and the BITs currently applicable.

71 According to UNCTAD, 'FDI into South Africa, by contrast, decreased markedly by 69 per cent to $\$ 1.8$ billion - the lowest level in ten years - owing to factors such as lacklustre economic performance, lower commodity prices and higher electricity costs' (UNCTAD Report 2016, p. 41). 